\title{
Protein S100-A8
}

National Cancer Institute

\section{Source}

National Cancer Institute. Protein S100-A8. NCI Thesaurus. Code C29927.

Protein S100-A8 (93 aa, $11 \mathrm{kDa}$ ) is encoded by the human S100A8 gene. This protein is involved in calcium and zinc binding and in the modulation of leukocyte functions. 